\title{
Review
}

\section{Steffen Mannuß*}

\section{Influence of different methods and anticoagulants on platelet parameter measurement}

\author{
https://doi.org/10.1515/labmed-2020-0037 \\ Received March 25, 2020; accepted August 26, 2020; published \\ online September 17, 2020
}

\begin{abstract}
Platelets are the smallest and perhaps the most versatile components of human blood. Besides their role in coagulation and the maintenance of vascular integrity, they are involved in many physiological processes, ranging from immune response and leukocyte recruitment to the production of antimicrobial peptides and immune-suppressive factors like TGF- $\beta$. These versatile abilities make platelets interesting for researchers from different disciplines. However, beside profound investigation into platelets' physiological role, there is a need for correct, standardized and thus reproducible quantification of platelet parameters. Mean platelet volume (MPV) is a widespread prognostic marker for several conditions, such as, acute coronary syndrome, chronic kidney disease and liver cirrhosis. Platelet activation is regarded as a marker for inflammatory processes, for example in autoimmune diseases such as type-1 diabetes, systemic lupus erythematosus and rheumatoid arthritis. The monitoring of platelet function is relevant for patients receiving antiplatelet medication. Platelet parameter measurement is affected by the choice of in vitro anticoagulant, the measurement technology and the time delay after sampling. This review focuses on the pre-analytical variability that arises as a result of the use of different in vitro anticoagulants and analyzer technologies when determining platelet parameters, since, even approximately 180 years after the discovery of platelets, there is still no standardized procedure.
\end{abstract}

Keywords: in vitro anticoagulation; mean platelet volume; measurement technology; platelet activation; platelet counting; platelet function.

\footnotetext{
*Corresponding author: Steffen Mannuß, Klinikum der Stadt Ludwigshafen, Institut für Labordiagnostik, Hygiene und Transfusionsmedizin, Ludwigshafen, Germany, Phone: +49 0621
} 5033609, E-mail: mannuss@klilu.de

\section{Introduction}

\author{
From "blood granules" and "colorless \\ beads"
}

It is not clear to whom the initial description of the platelet and its function is actually attributable. In 1836, Hermann Nasse described his microscopic blood observation, stating that in addition to the "blood globules," there are also "blood granules," which "combine to form irregular, elongated piles (flakes)" [1].

In 1865, Max Schultze described in his work Ein heizbarer Objecttisch und seine Verwendung bei Untersuchungen des Blutes "lumps of colorless beads" and referred to preliminary studies by his colleague Schulten from 1858 , who found "white bodies in large numbers and of very different size so that the smallest had scarcely half the size of the larger blood disks, whereas the largest had probably double and three times the same" $[2,3]$.

In contrast to Schulten, who attributed his observation to the "puerperal fever" of his examined patient, Schultze assumed a "normal form-factor" of human blood.

In 1882, Julius Bizzozero's work Ueber einen neuen Formbestandtheil des Blutes und dessen Rolle bei der Thrombose und der Blutgerinnung dealt with the observations made by his colleagues and their different methods of microscopic blood examination. He was the first to recognize the role of platelets as a functional component of blood clotting, and he investigated the various substances he and his colleagues used experimentally to prevent coagulation. Some of his medical colleagues, such as Riess, rejected the idea that platelets are involved in coagulation, since one can indeed see them even before the same. Rather, they are decay products of white blood cells [4]. It was not until 1897 that William Duke recognized in the case of a young man who suffered from thrombocytopenia a correlation of measured platelet count and bleeding time. He observed that the increased platelet count after a transfusion led to a shortening of the duration of bleeding and thus realized that the platelets were apparently necessary for hemostasis. He concluded from his observations that 
thrombocytopenia is the cause of a purpura [5]. In the same year, James Homer Wright, in the context of staining experiments and microscopic observations, investigated the origin of platelets and came to the conclusion that platelets emerge by detaching from megakaryocytes of the bone marrow. He published the results of his investigations in his 1910 work "The Histogenesis of the Blood Platelets," in which he critically examines his colleagues' theories of platelet development $[6,7]$.

After their detachment from megakaryocytes, platelets are the smallest cellular constituent of human blood. Under physiological conditions, their number is about 150,000 to 450,000 per $\mu \mathrm{L}$ of blood, and the mean platelet volume (MPV) is between $5 \mathrm{fL}$ and $13 \mathrm{fL}$, depending on the applied method of measurement, the in vitro anticoagulant and the time delay between blood sampling and measurement $[6,8-10]$.

\section{In vitro anticoagulation}

The choice of an appropriate in vitro anticoagulant is a prerequisite for the correct measurement of hematological analytes and must be taken into consideration when interpreting the results. The requirements for an appropriate anticoagulant include the correct representation of the in vivo situation and the time-dependent stability of parameters, as there are undefined or not always controlled time periods between blood collection and measurement.

The anticoagulant of choice for blood cell counting is ethylene-diamine-tetraacetate (EDTA). Its anticoagulant properties (chelation of divalent cations, such as $\mathrm{Ca}^{2+}$-ions) were already investigated in the 1940s [11], and, after its introduction to the hematological laboratory in 1951 [12], EDTA became an established anticoagulant. Since the early 1990s, EDTA has been the standard anticoagulant for the determination and counting of blood cells [13]. There are several formulations available, namely $\mathrm{Na}_{2}$ EDTA, $\mathrm{K}_{2}$ EDTA and $\mathrm{K}_{3}$ EDTA $[14,15]$ and although the International Council for Standardization in Hematology (ICSH) recommends the usage of $\mathrm{K}_{2}$ EDTA [13], the $\mathrm{K}_{3} \mathrm{EDTA}[14,15]$ and $\mathrm{Na}_{2}$ EDTA formulations (in combination with sodium fluoride for the measurement of blood glucose) [16] are still in use. Well-known phenomena are the loss of discoid shape and the time-dependent swelling of platelets, resulting in an increase of the MPV in EDTA anticoagulated blood samples [15, 17, 18]. Thompson et al. found that the $\mathrm{K}_{3}$ EDTA formulation causes greater platelet swelling over time than the $\mathrm{Na}_{2}$ EDTA formulation [19]. Electron microscopic investigations of platelet ultrastructure revealed that platelets thereby undergo a shape change and form pseudopods [18]. Besides the impact on MPV, another rare but relevant shortcoming of EDTA is the phenomenon known as "EDTA-dependent pseudo-thrombocytopenia" (PTCP). The first description of platelet agglutination by a serum factor in EDTA anti-coagulated blood dates to 1969 [20]. The prevalence of this in vitro phenomenon is reported in the literature as 0.1 to $0.21 \%$ [14, 21]. Conversely, 1.25 to $15.3 \%$ of all thrombocytopenic patients are pseudo-thrombocytopenic cases [15]. Failure to detect the presence of PTCP can lead to misdiagnosis and incorrect treatment decisions. A large number of such cases has been documented [22-24], and diagnosis is further complicated by the fact that in some cases the phenomenon is transient [25-28]. The basis of an EDTA-dependent PTCP is auto-antibodies directed against the platelet fibrinogen receptor GpIIb/IIIa, which is unmasked by EDTA [14]. Since such a phenomenon has also been described for other in vitro anticoagulants [29], partial combined incompatibilities occur [30-33], and the in vitro agglutination does not necessarily lead to a platelet count that defines as thrombocytopenia [34], the correct term should be "anticoagulant-induced platelet agglutination."

A reliable anticoagulant for the correct determination of platelet counts in cases of anticoagulant-induced platelet agglutination is magnesium sulfate $\left(\mathrm{MgSO}_{4}\right)[30,34]$.

Bizzozero had already described $\mathrm{MgSO}_{4}$ as "the best anticoagulant salt" in 1882, and it had previously been used experimentally by Hayem (1878) and Hoffman (1881) to microscopically examine blood samples on glass slides [4]. In 1909, Anton Fonio anti-coagulated capillary blood for a microscopic platelet count with a $14 \% \mathrm{MgSO}_{4}$ solution [35].

In 1986, the Japanese working group of Nakamoto successfully used $\mathrm{MgSO}_{4}$ as an in vitro anticoagulant to determine the actual platelet count in cases of EDTA-induced PTCP [36]. Since the results of this study were solely published in a Japanese journal, they remained widely unrecognized. In addition, a study published in 2002 on hematological examinations of $\mathrm{MgSO}_{4}$ anticoagulated blood by Kondo and colleagues did not lead to a widespread use of $\mathrm{MgSO}_{4}$ as an anticoagulant in the hematological laboratory [37]. An article by Schuff-Werner and colleagues published in 2013 that proved the correction of platelet counts in cases of EDTA-induced PTCP using $\mathrm{MgSO}_{4}$ anti-coagulated blood collection systems [34] finally resulted in the commercial introduction of $\mathrm{MgSO}_{4}$ as an in vitro anticoagulant into the laboratory routine. The diverse effects of magnesium salts on coagulation, both at the cellular and plasmatic levels, have been described in several studies [38-40]. A dose-dependent inhibition of platelet-derived thromboxane A2 synthesis [40] and 
inhibition of ADP and arachidonic acid inducible platelet aggregation [34] by $\mathrm{Mg}^{2+}$ were demonstrated.

Investigations of the plasmatic coagulation are routinely performed with citrate anti-coagulated blood samples [41]. As early as 1891, Pekelharing found that the effect of $\mathrm{Ca}^{2+}$ on the course of blood clotting can be neutralized by the addition of sodium citrate [42]. Citrate is the salt of citric acid that binds with free $\mathrm{Ca}^{2+}$ ions and thus removes them from the coagulation cascade. The anticoagulant effect of citrate is reversible by the addition of $\mathrm{Ca}^{2+}$ to the sample material [43]. When determining absolute cell counts from citrate anti-coagulated blood sampling devices, the dilution effect from the addition of liquid citrate has to be considered and the results corrected by the factor 1.1 [44]. Due to osmotic effects, a reduced platelet and erythrocyte volume in citrate anti-coagulated blood samples is observed which is not the case with EDTA anticoagulated blood [19]. In addition to laboratory procedures, citrate anticoagulation is also used in renal replacement therapy [45].

The first description of heparin dates to 1918, when William Henry Howell and Emmett Holt devoted themselves to the identification and characterization of coagulation factors. Just two years earlier, Howell's colleague Jay McLean had extracted substances from animal livers that showed in vitro anticoagulant activity [46]. Howell and Holt reopened McLean's preliminary studies and succeeded in extracting a phosphatide, which was henceforth referred to as heparin because of its high content in the liver [47]. Heparin acts as an anticoagulant by multiplying the activation of antithrombin III (AT III) [48]. In laboratory medicine, heparin is used in the formulations lithium heparinate or sodium heparinate for the investigation of clinical chemistry parameters and electrolytes in blood plasma [49]. Heparin is not recommended for microscopic investigations of blood cells because it interferes with the cells' staining properties $[44,50]$.

In 1884, John Haycraft described in his work "On the action of a secretion obtained from medicinal leech on the coagulation of the blood" experiments that dealt with the anticoagulant properties of the saliva of leeches [51]. Hirudin is derived in particular from the leech Hirudo medicinalis, and acts as anticoagulant by the inhibition of thrombin. It binds with high affinity, thereby preventing the thrombin-induced conversion of fibrinogen to fibrin [52]. Since the composition and concentration of the electrolytes in the sample material are not affected, hirudin anti-coagulated blood collection systems are suitable for the investigation of platelet function by impedance aggregometry [53].

\section{Impact of in vitro anticoagulation on platelet count and MPV}

Since the addition of the platelet count to the automated full blood count in the 1970s, several studies have focused on the comparability and time-dependent stability of platelet counts and MPV in differently anti-coagulated whole blood samples [19, 54-58]. These studies show that platelet counts as well as MPV are affected by the choice of in vitro anticoagulant. Perrotta and colleagues investigated sodium citrate as an alternative to EDTA in order to enhance efficiency in hematological analysis. They concluded that citrate is suitable for blood cell counting if the dilution is corrected by a factor of 1.1. The MPV as measured in citrate samples is about $1.4 \mathrm{fL}$ lower than in respective EDTA samples and the platelet counts about $10 \times 10_{9} / \mathrm{L}$ less. However, they did not investigate the timedependent stability of platelet counts and MPV [44]. Thompson and colleagues concluded that sodium citrate and heparin proved unreliable for MPV measurements due to a decrease of MPV after $8 \mathrm{~h}$, whereas, in $\mathrm{Na}_{2}$ EDTA and $\mathrm{K}_{3}$ EDTA samples, after an initial increase during the first $2 \mathrm{~h}$, the MPV remained stable up to $8 \mathrm{~h}$. However, the MPV variations over time of all investigated anticoagulants were not more than $5-7 \%$. The platelet counts, except in the heparin anti-coagulated samples, were similar, but, in contrast to the $\mathrm{Na}_{2}$ EDTA and $\mathrm{K}_{3}$ EDTA samples, the platelet counts in the citrate samples tended to decrease over time in some samples [19]. McShine and colleagues state that the MPV is around $6-13 \%$ lower in citrated samples as compared to the respective EDTA samples [55], which is in accordance with the observation of Dastjerdi et al., who show that the mean MPV measured from citrated samples was $0.66 \mathrm{fL}$ (9\%) lower than from the respective EDTA samples when measured within $1 \mathrm{~h}$ after sampling [56], and Mannuß et al., who found a difference of $1.32 \mathrm{fL}(13.5 \%)$ after $180 \mathrm{~min}$ [8]. The observations of McShine, Dastjerdi and Mannuß are also consistent regarding the platelet count. McShine and colleagues state that in EDTA samples the platelet count became stable after $1 \mathrm{~h}$, whereas the platelet count in citrate samples continued to drop about $18-30 \%$ for $4-6 \mathrm{~h}$ [55]. Dastjerdi and colleagues state that the mean platelet count measured from citrate samples was $36 \%$ less than from the respective EDTA samples within one hour after sampling [56] and Mannuß et al. state that the immediately measured platelet count in citrate samples is $15 \%$ lower than in the respective EDTA samples. After $180 \mathrm{~min}$, the difference amounts to $26 \%$. The platelet count in $\mathrm{MgSO}_{4}$ samples was intermediate and remained most stable for $180 \mathrm{~min}$ [8]. 
O'Malley et al. investigated a variety of antiplatelet mixtures based on EDTA and citrate. Their results indicate that in the commercially available citrate formulation (3.2\% trisodium citrate) the MPV is lower in comparison with EDTA and also increases markedly less over time [58]. Bath and colleagues show that interpreting the results of MPV measurements is further complicated by different citrate concentrations that are commercially available and cause more or less pronounced platelet swelling [54]. Taking that into account for EDTA and citrate, one can see that, besides the choice, the formulation and concentration of the respective anticoagulant also affect platelet parameters.

The time-dependent changes of MPV in EDTA and citrate anti-coagulated blood must be taken into account because elevated and decreased MPV levels are associated with a great number of pro-inflammatory diseases [59] and are therefore used as prognostic markers [60-62]. The time delay between sampling and measurement of samples can produce an artificially altered MPV, which misrepresents the in vivo situation. Lance and colleagues therefore recommend the MPV measurement in EDTA samples after $120 \mathrm{~min}$ and in citrate samples after 60 min, respectively [57].

However, standardized pre-analytic conditions for studies that evaluate MPV as potential marker are not established. Beyan and Beyan reviewed 181 studies on MPV and found that $47.5 \%$ did not state the time-delay between blood sampling and measurement and that $33.1 \%$ did not even mention the type of anticoagulant used [63]. Lancé and colleagues state that from 61 reviewed studies, only two were sufficiently standardized by stating the anticoagulation, the time delay after sampling and the measurement method [17]. These shortcomings led to new editorial policy that proposed minimum requirements for manuscripts focusing on the association of MPV with certain conditions [64].

Alternative in vitro anticoagulants such as hirudin seem to be much less of a matter of interest for the measurement of platelet counts and MPV, as there are not many studies dealing with this topic. Kumura and colleagues compared EDTA and hirudin anti-coagulated blood for hematology tests and found that hirudin proved unreliable for delayed measurement of platelet counts due to complete coagulation of the samples after $4 \mathrm{~h}$. If the platelet count is measured within $2 \mathrm{~h}$ after sampling, there is no difference in the values of the respective EDTA samples [65]. However, they used a solution containing $2 \mu \mathrm{g} / \mathrm{mL}$, which is much lower than the concentration of $25 \mu \mathrm{g} / \mathrm{mL}$ in commercially available blood sampling devices [66]. Instead of the concentration, some authors state the antithrombotic power of the hirudin formulations in antithrombotic units (ATU). Menssen et al. investigated the hirudin concentration required for anticoagulation and showed that a hirudin concentration of at least 200 ATU/ $\mathrm{mL}$ is sufficient for automated blood cell counting and $300 \mathrm{ATU} / \mathrm{mL}$ prevents blood clotting for at least $24 \mathrm{~h}$ [67]. In samples containing $1000 \mathrm{ATU} / \mathrm{mL}$, the difference in platelet counts between hirudinized blood and EDTA blood was, although statistically significant, small in absolute terms and thus not clinically relevant. Microscopic investigations revealed that platelet micro aggregates (PMA) occur more frequently in blood films of hirudinized blood than in the respective EDTA blood and a hirudin concentration of $400 \mathrm{ATU} / \mathrm{mL}$ and above is required to minimize this phenomenon. However, in some cases, even high concentrations up to $2000 \mathrm{ATU} / \mathrm{mL}$ could not totally prevent PMA formation [67]. These findings are confirmed by a recent communication from Chapman and Favaloro, who describe a decline of platelet count in manufacturer recommended hirudin devices (up to 60\%) within $4 \mathrm{~h}$ after sampling and the emerging of PMA in $50 \%$ of the samples. Although respective citrate samples also show the trend to decreasing platelet counts (up to $40 \%$ ), the emerging of PMA is less frequent. No PMA formation can be observed in EDTA tubes and the platelet count varied $<10 \%$ over $4 \mathrm{~h}$ [68]. These findings and the high costs of hirudin contradict the routine application of hirudin anti-coagulated blood sampling devices for platelet counting.

Table 1 summarizes the properties and limitations of anticoagulants that are routinely applied for the measurement of platelet parameters.

\section{Technologies for the measurement of platelet parameters}

At the time when platelets were described by Bizzozero as an independent blood constituent [4], the physiological platelet count was not well-known. Bizzozero's colleague Hayem, who considered platelets to be precursors of erythrocytes and therefore called them "hematoblasts", had already made microscopic counts of neonatal, pediatric and adult blood samples, and found a physiological "hematoblast number" of, depending on the age group, 200,000 to 346,000 per $\mu \mathrm{L}$ [69]. Microscopy, or chamber counting, was the only means of platelet counting until the development of the impedance measurement method by Wallace Coulter in 1953 [70]. The automated measurement of cell counts and cell volumes is now part of the laboratory routine. For specialized questions, such as the measurement of functional parameters and the degree of activation, various methods are available, which are described in the following section. 


\section{Microscopic platelet counting according to Fonio}

When platelets are counted according to Fonio, capillary blood is taken up in a drop of $14 \% \mathrm{MgSO}_{4}$ solution and a dried preparation is produced therefrom, which is then dyed according to Jenner or Giemsa. The next step is to count how many platelets are detected by the microscopic counting of 1,000 erythrocytes. The ratio of erythrocyte count to platelet count as determined by this approach allows the derivation of the platelet count based on the total number of erythrocytes [35].

\section{Direct microscopic platelet counting according to Brecher}

An advance in the microscopic platelet count (counting chamber method) was achieved in 1953 by the introduction of phase-contrast microscopy, as this method allows platelets to be more clearly distinguished from cell debris [71, 72]. Brecher's approach to direct microscopic counting has been used since 1988 as a reference method for the manual determination of the platelet count [73]. In this case, the blood is mixed with a hypotonic ammonium oxalate solution, resulting in a lysis of the interfering erythrocytes and allowing the microscopic platelet count in a Neubauer counting chamber.

\section{Automated platelet counting}

\section{Impedance method (Coulter principle)}

The impedance measurement method developed by Wallace Coulter in 1953 [70] is based on the fact that blood cells cause a measurable increase in electrical resistance when they pass through a measuring chamber to which an electrical voltage is applied. The extent of the increase in resistance is proportional to the volume of the passing particles. As a result, this measuring principle not only detects the number of cells but also provides volume information concerning the detected cells and thus allows a distinction of platelets from erythrocytes [71].

The device software of the XE 2100, the XE 5000 and the XN series (Sysmex, Norderstedt, Germany) sums up the results of the impedance measurement to create a histogram, which is limited by two discriminators that adapt flexibly to the position of the histogram. The lower discriminator flexibly captures particles between 2 and $6 \mathrm{fL}$, whereas the upper discriminator covers those in the range of $12-30 \mathrm{fL}$. By adapting the discriminators to the location of the platelet distribution curve, erythrocyte fragments at the upper end or cell debris at the lower end of the histogram are excluded [71, 74].

The DxH 800 (Beckman Coulter, Krefeld, Germany) identifies particles between 2 and $20 \mathrm{fL}$ as platelets. The pulses are generated by three measuring cells, from each of which 64-channel histograms are created. The device software identifies the two lowest points and the highest point within the distribution curves and places a logarithmic normal distribution curve over these points. From the curve generated, covering the range from 0-70 fL, the platelet count is deduced by assigning cells with a volume of 2-20 fL to the platelet fraction $[71,75]$.

\section{Scattered light optical method}

An alternative approach for the identification and counting of cells is the scattered light optical method, as utilized by the Advia 120 (Siemens, Eschborn, Germany). In a first step, the blood cells are brought into a spherical shape by means of an iso-osmotic reagent

Table 1: Properties of different routineously applied in vitro anticoagulants.

\begin{tabular}{|c|c|c|c|c|}
\hline Anticoagulant & Anticoagulant properties & Application & Positive features & Negative features \\
\hline EDTA & $\begin{array}{l}\text { Chelation of divalent cat- } \\
\text { ions, e.g. } \mathrm{Ca}^{2+}\end{array}$ & $\begin{array}{l}\text { Routine hematology and } \\
\text { blood cell counting }\end{array}$ & $\begin{array}{l}\text { Good preservation of } \\
\text { cellular components and } \\
\text { morphology of blood cells }\end{array}$ & $\begin{array}{l}\text { Time-dependent increase of } \\
\text { MPV and induction of } \\
\text { platelet activation }\end{array}$ \\
\hline Heparin & $\begin{array}{l}\text { Activation of antithrombin } \\
\text { III }\end{array}$ & $\begin{array}{l}\text { Measuring of clinical chem- } \\
\text { istry parameters }\end{array}$ & $\begin{array}{l}\text { Suitable for several platelet } \\
\text { function tests }\end{array}$ & $\begin{array}{l}\text { Interference with the stain- } \\
\text { ing properties of cells }\end{array}$ \\
\hline Citrate & Binding of $\mathrm{Ca}^{2+}$ ions & $\begin{array}{l}\text { Testing of plasmatic } \\
\text { coagulation }\end{array}$ & $\begin{array}{l}\text { Applicable for multiple test } \\
\text { settings }\end{array}$ & $\begin{array}{l}\text { Lower platelet counts (up to } \\
36 \% \text { ) than in EDTA }\end{array}$ \\
\hline Hirudin & $\begin{array}{l}\text { Specific inhibition of } \\
\text { thrombin }\end{array}$ & Impedance aggregometry & $\begin{array}{l}\text { No affection of the samples' } \\
\text { electrolyte composition }\end{array}$ & $\begin{array}{l}\text { Time-dependent formation } \\
\text { of PMA }\end{array}$ \\
\hline $\mathrm{MgSO}_{4}$ & $\begin{array}{l}\text { Inhibition of fibrinogen- } \\
\text { mediated aggregation }\end{array}$ & $\begin{array}{l}\text { Platelet counting in cases of } \\
\text { PTCP }\end{array}$ & $\begin{array}{l}\text { Reliable platelet counts in } \\
\text { cases of PTCP from } \\
\text { multiple anticoagulants }\end{array}$ & $\begin{array}{l}\text { Not suitable for impedance } \\
\text { aggregometry }\end{array}$ \\
\hline
\end{tabular}


containing an additive called "surfactant," and a laser diode-generated monochromatic light beam is then directed to the flow cell $[75,76]$. Through the application of the Mie theory of scattered light properties, which states that the intensity of monochromatic scattered light measured at a certain angle depends on the volume of a cell and the difference in the refractive indices of cell and medium, information about the illuminated particle can be derived [76, 77]. The scattered light generated at the cell is measured by photodiodes, which are positioned at two different angles. The signal of the low-angle light scattering at $2-3^{\circ}$ is amplified 30 times and gives information about the volume of the cell (MCV or MPV). The signal of the high-angle light scattering at $5^{\circ}$ to $15^{\circ}$ is amplified 12 times and reveals the refractive index (RI) of a cell and allows determining its density [78]. Thus, due to the refraction, cell fragments are distinguished from platelets [71]. Using these two parameters, the device software generates a scattergram in which the platelets are identified by their volume (1$30 \mathrm{fL})$ and their RI $(1.35-1.40)[78,79]$. The information is converted into cell volume and density using the Mie theory [77]. The ability to measure even platelets of small size that would otherwise be excluded by the lower discriminators of the impedance method is an advantage of the scattered-light method. In contrast, large platelets, which are identified as erythrocytes in the impedance method corresponding to the upper discrimination, can be correctly assigned to the platelet fraction on the basis of their lower RI [71].

The CELL-DYN Sapphire (Abbott, Wiesbaden, Germany) utilizes, additional to an impedance method, the proprietary MAPSS ${ }^{\mathrm{TM}}$ technology, which is also a scattered light optical method but the technical approach differs from the Advia system. Platelets are identified by scattered light intensity at $7^{\circ}$ and $90^{\circ}$ angles and a scattergram is produced from this information, discriminating platelets from nonplatelet particles by floating thresholds [80].

The recently launched Alinity hq analyzer (Abbott, Wiesbaden, Germany) exclusively utilizes an improved scattered light optical MAPSS ${ }^{\mathrm{TM}}$ technology. The information from seven unique light detectors, detecting the polarized and depolarized side scatter, axial light loss and four intermediate angles of light scatter are combined with fluorescence detection and therefrom a unique signal signature of each cell is generated [81].

\section{Flow cytometry}

The utilization of flow cytometry allows the rapid and automated identification, counting and sorting of different cell populations. The cells, suspended in a hydrodynamically focused liquid flow, pass a measuring chamber and are thereby illuminated by a monochromatic light beam (laser). Depending on their size and cell structure, the laser light is scattered at certain angles and detected by differently arranged photocells. Different cells are identified by a change in the scattering angle of the detected forward and side scattered light, respectively. These changes allow the identification of the passing cells. By further modifications of this principle, for example the use of fluorescent dyes and fluorochrome-labeled antibodies, one can gain additional information, such as the RNA/DNA content of the cell or the expression of surface markers [82, 83].

Analyzers of the XE-series, as well as the CELL-DYN Sapphire feature a fluorescence-optical counting method (PLT-0). It is activated when the analyzer runs in the "reticulocyte mode" [84, 85]. The fluorescence-optical method is based on the staining of the cellular nucleic acids with a fluorescent dye after prior partial lysis of the cell membrane. In the flow cell, the different cell populations can be differentiated by their forward scattered light and the fluorescence intensity, which is dependent on the nucleic acid content $[85,86]$. Due to their larger amount of RNA, immature platelets (reticulated platelets) can be distinguished from mature platelets by this method. Since the life span of immature platelets is about $24-36 \mathrm{~h}$, their proportion reflects the recent state of thrombopoiesis, allowing the distinction of decreased platelet production from increased peripheral platelet destruction $[87,88]$. For the automated quantification of reticulated platelets, the analyzers of the XE-series report the immature platelet fraction (IPF) [89], whereas the Cell-Dyn Sapphire reports "reticulated platelets" (retPLT) as proportion of the respective total optical platelet count [85]. However, IPF and retPLT are essentially different methods and cannot be used interchangeably [88]. This is in accordance with the observations of Meintker and colleagues, who state that the IPF and retPLT methods show only a moderate interinstrument correlation and have different reference ranges (retPLT: $1.0-3.8 \%$; IPF: 0.8-7.9\%). They further state that the separation of patient groups with high platelet turnover like immune thrombocytopenia from control groups is better achieved with the retPLT method [90]. IPF was shown to be useful for the evaluation of platelet recovery after chemotherapy [91], stem cell transplantation [92] and dengue [93]. Additionally, IPF was investigated as a marker for the prognosis of myelodysplastic syndromes [94] and sepsis [95]. Although reticulated platelets are routineously measured from EDTA anti-coagulated blood, Nishiyama and colleagues recommend the application of CTAD anticoagulated blood from patients with chronic ITP [96]. 
However, the PLT-O method does not allow the determination of the platelet volume. The analyzer utilizes a switching algorithm to report the apparently correct platelet count. If the algorithm detects an affected platelet distribution curve (e.g., due to fragmented red blood cells) the analyzer switches to report the platelet count as measured by the fluorescence-optical method. If the fluorescence-optical method is affected (e.g., due to fragmented leukocytes), the platelet count as derived from the impedance method is reported [84]. Briggs and colleagues also report that it is somehow "widespread practice" to override the switching algorithm and solely rely on the fluorescence-optical derived platelet count. This is a critical issue, as Mannuß and colleagues demonstrated that, depending on the applied in vitro anticoagulant, the platelet counts of both methods may differ significantly [8].

The analyzers of the XN series (Sysmex, Norderstedt, Germany) are equipped with a fluorescence-optical channel (PLT-F), in which platelets are stained with a fluorescent RNA dye and are irradiated with a semiconductor laser beam. The resulting forward scattered light and side fluorescence intensities of each platelet are detected and the information plotted on a 2D scattergram. The PLT-F method is regarded as preferable to the PLT-O method due to its ability to discriminate apoptotic leukocytes from platelets and its more accurate estimation of platelets in thrombocytopenic samples [74, 97-100].

Since 2001, the flow cytometric approach using the monoclonal antibodies CD41 and CD61 has been the reference method for platelet counting. The so determined platelet count is set in relation to the number of erythrocytes as measured by impedance in EDTA anti-coagulated whole blood samples (RBC/Platelet Ratio Method) [101].

The CELL-DYN Sapphire is equipped with the CD61immunoplatelet method, which is based on a fluorescein isothiocyanate conjugated monoclonal antibody directed against the platelet glycoprotein IIIa. Platelets are identified by the fluorescence channel FL1 and scattered light detection at $7^{\circ}$ and $90^{\circ}$ [80]. Trabuio and colleagues compared the platelet counts as measured from the CD61-immunoplatelet method with the respective counts from the CD41/CD61 reference method and found that the results of both methods correlated well [102].

Table 2 sums up the different technical approaches for the automated determination of platelet counts.

Since activated platelets show an increased expression of P-selectin (CD62p) and granulophysin (CD63) to mediate the interaction with endothelial cells and leukocytes [103, 104], reliable flow cytometric approaches for the determination of platelet activation status are the measurement of the proportion of CD62p- and CD63-positive platelets as well as the actual formation of platelet-leukocyte complexes (as measured by platelet antigen-bearing leukocytes) [105].

\section{Impact of analyzer technology on platelet count and MPV}

As early as 1985, Towbridge and colleagues compared MPV and platelet count, as measured with an impedance-based analyzer (Coulter S Plus) and a light scattering-based analyzer (Technicon H6000) in K2-EDTA anti-coagulated blood samples. Besides the time-dependent increase of MPV by $17 \%$ (during $39 \mathrm{~h}$ of sample storage), as measured by impedance, they also observed a decrease in the MPV by $22 \%$ when measured by light-scattering. However, the concomitant platelet counts in both systems changed by less than $4 \%$. Towbridge et al. concluded that as long as the procedures of MPV measurement are not standardized, the clinical value of MPV cannot be assessed [106]. Interestingly, three decades later, an approach to MPV measurement has still not been standardized [63].

In 2012, Latger-Cannard and colleagues compared impedance-based analyzers (XE 2100 and LH 750) and a light scattering-based analyzer (Advia 2120) with regard to the standardization of MPV measurement with K2-EDTA anti-coagulated samples. In accordance with Towbridge et al. [106] and Mannuß et al. [107], they report lower MPV values from light scattering-based analyzers but the difference between the MPV values as obtained by both impedance-based methods is even larger [75].

Mannuß and colleagues not only compared EDTA anticoagulated samples but also $\mathrm{MgSO}_{4}$ anti-coagulated samples using impedance-based (XE 5000 and $\mathrm{DxH}$ 800) and a light-scattering-based analyzer (Advia 120) regarding platelet count and MPV measurement. The results of their investigation show that, in EDTA anti-coagulated samples, a significantly higher MPV is measured on the XE 5000 than on the DxH 800 and the Advia 120. As mentioned previously, this phenomenon had already been reported for the previous model XE 2100D from Sysmex and also for the $\mathrm{LH} 750$ from Beckman Coulter [75]. In $\mathrm{MgSO}_{4}$ anticoagulated samples, a lower MPV is measured than in EDTA anti-coagulated samples when performed by impedance method. However, if the measurement is performed using the scattered light method (Advia 120), the MPV measured from $\mathrm{MgSO}_{4}$ samples is almost $1 \mathrm{fl}$ higher than that from EDTA samples. This outcome is most likely due to the measuring principle of the Advia 120. The hypothesis that $\mathrm{MgSO}_{4}$ has an impact on cell volume and 
Table 2: Different methods of automated platelet counting.

\begin{tabular}{|c|c|c|c|c|}
\hline Method & Technological approach & Positive features & Negative features & Analyzer \\
\hline Impedance method & $\begin{array}{l}\text { Particles cause an increase in electrical } \\
\text { resistance, which is proportional to } \\
\text { their respective volumes }\end{array}$ & $\begin{array}{l}\text { Simultaneous generation of cell } \\
\text { count and cell volume }\end{array}$ & $\begin{array}{l}\text { Interference from cell debris } \\
\text { may occur }\end{array}$ & $\begin{array}{l}\text { XE series } \\
\text { XN series } \\
\text { LH } 750, \text { DxH } \\
800 \\
\text { CELL-DYN } \\
\text { series }\end{array}$ \\
\hline $\begin{array}{l}\text { Fluorescence opti- } \\
\text { cal method }\end{array}$ & $\begin{array}{l}\text { Staining of nucleic acids / platelet } \\
\text { granules with fluorescent dyes }\end{array}$ & $\begin{array}{l}\text { Detection of giant platelets and } \\
\text { exclusion of nonplatelet parti- } \\
\text { cles from the count }\end{array}$ & $\begin{array}{l}\text { The measurement of platelet } \\
\text { volumes is not possible }\end{array}$ & $\begin{array}{l}\text { XE series } \\
\text { XN series }\end{array}$ \\
\hline $\begin{array}{l}\text { Scattered light op- } \\
\text { tical method }\end{array}$ & $\begin{array}{l}\text { Detection of scattered light after irradi- } \\
\text { ation of cells with monochromatic } \\
\text { light }\end{array}$ & $\begin{array}{l}\text { Exclusion from cell fragments and } \\
\text { detection of giant platelets }\end{array}$ & $\begin{array}{l}\text { Altered refractive indices } \\
\text { may lead to wrong cell } \\
\text { assignment }\end{array}$ & $\begin{array}{l}\text { Advia series } \\
\text { CELL-DYN } \\
\text { series } \\
\text { Alinity hq }\end{array}$ \\
\hline $\begin{array}{l}\text { Immunological } \\
\text { method }\end{array}$ & Labeling of platelets with anti-CD61 & $\begin{array}{l}\text { Strong correlation with the CD41/ } \\
\text { CD61 reference method }\end{array}$ & $\begin{array}{l}\text { Inappropriate in cases of } \\
\text { Glanzmann } \\
\text { thrombasthenia }\end{array}$ & $\begin{array}{l}\text { CELL-DYN } \\
\text { series }\end{array}$ \\
\hline
\end{tabular}

refractive index is supported by the observation of Francois and colleagues [108], who, when measured in $\mathrm{MgSO}_{4}$ anticoagulated blood, found very small ungranulated particles in the platelet diffraction pattern outside the platelet gate.

Within $24 \mathrm{~h}$, the mean MPV of the EDTA samples as measured with the Advia 120 increases by $1.9 \mathrm{fL}$ and by $0.7 \mathrm{fL}$, in $\mathrm{MgSO}_{4}$ anti-coagulated samples, respectively. In contrast, when measured with the XE 5000 and DxH 800, low volume increases in the range of $0.2-0.4 \mathrm{fL}$ in the EDTA samples and $0.1 \mathrm{fL}$ to $0.2 \mathrm{fL}$ in the $\mathrm{MgSO}_{4}$ samples are measured. From this perspective, the impedance technology proves superior to scattered light technology for the measurement of platelet count and MPV after delayed sample processing.

The assumption that the impedance method of the XE 5000 fails to fully detect platelets in $\mathrm{MgSO}_{4}$ anticoagulated samples although they are obviously present is supported by the fact that the fluorescence-optical method of the XE 5000 measures significantly higher platelet counts, which differ only insignificantly from the values of the EDTA anti-coagulated samples. The situation is different with comparative measurements of platelets in citrate anti-coagulated blood. Although higher values can be measured using the fluorescenceoptical method than with the impedance method, the difference to the fluorescence-optic measured values of the EDTA and $\mathrm{MgSO}_{4}$ samples is still significant [8]. Possible reasons for this are either the dilution effect, which is not completely corrected by the factor of 1.1, or poorer staining properties of the fluorescent RET-SEARCH reagent in citrate anti-coagulated blood. However, it cannot be ruled out that platelets in citrated blood vanish in a time-dependent manner or form smaller aggregates, as Shimizu and colleagues, who investigated the blood samples of patients with a suspected hyperaggregable state of platelets, found aggregate formation in citrate anti-coagulated samples, which was not demonstrated in the respective EDTA anti-coagulated samples [109]. It is conceivable that during sample storage, the calcium reversibly bound by citrate is released, and the aggregate formation is thus favored.

The DxH 800 shows the smallest difference in platelet counts as measured in EDTA and $\mathrm{MgSO}_{4}$ samples, although the difference in MPV values is greatest [107]. The fact that the DxH 800 measures significantly lower MPV values in both EDTA and $\mathrm{MgSO}_{4}$ anti-coagulated blood than the XE 5000, which is also based on the impedance measurement method, is likely due to the fact that the DxH 800 can detect platelets that are as small as $2 \mathrm{fl}$ on its logarithmic normal distribution curve [110]. Furthermore, the platelet counts on the XE 5000 and $\mathrm{DxH}$ 800 devices remain stable over $24 \mathrm{~h}$ in both EDTA and $\mathrm{MgSO}_{4}$ anti-coagulated samples, whereas the measurement on the Advia 120 device shows a marked decrease in the mean platelet counts of the tested population (around $40 \times 10_{9} / \mathrm{L}$ ) for both anticoagulants [107].

As mentioned with regard to the observation of Francois and colleagues [108], it is quite conceivable that timedependent alterations of the refractive indices lead to an incorrect assignment of the cells by the Advia 120 device software. Specially customized software to correct the altered refractive indices such as that used by Ahnadi and colleagues for citrate anti-coagulated samples [111] might also be relevant for $\mathrm{MgSO}_{4}$ anti-coagulated samples. 
These time-dependent alterations of the refractive index may also affect the scattered light optical platelet measurement of the CELL-DYN Sapphire and Alinity hq. Hedberg and Lehto state that the CBC parameters, as measured from EDTA anti-coagulated blood with the CELL-DYN Sapphire, proved to be stable for $24 \mathrm{~h}$, except the optical platelet count [112]. For samples aged over $24 \mathrm{~h}$ the impedance method provided more reliable results. However, the direct comparison of the platelet counting methods that are available on the CELL-DYN Sapphire using thrombocytopenic samples revealed that the impedance method overestimates platelet counts and in some cases even fails to provide any result [80].

The novel hematology analyzer Alinity hq is not equipped with impedance technology and solely utilizes an improved optical MAPSS ${ }^{\mathrm{TM}}$ method for platelet counting [113]. In contrast to the MAPSS ${ }^{\mathrm{TM}}$ technology of the CELL-DYN Sapphire, there are three additional low angle scatter detectors for an improved separation of platelets from erythrocytes [81]. Initial performance evaluations showed strong agreement and correlation of platelet counts as measured by the optical method of the Alinity hq and the immunological method of the CELL-DYN Sapphire $[81,113]$. Kwang-Sook and colleagues compared the Alinity hq with the Sysmex XN-9000 and confirm the good analytical performance but also state that all parameters were stable up to $36 \mathrm{~h}$ at room temperature except MPV [114]. Nevertheless, further comparisons of MAPSS ${ }^{\mathrm{TM}}$ technology with impedance methods, regarding long-term stability and the impact of different in vitro anticoagulants on platelet parameter measurement are required. Taken together, the results of the abovementioned studies reveal that, depending on the analyzer technique and the in vitro anticoagulation, the MPV measurements yield highly variable results. When considering these variables in addition to time-dependent changes, the mean MPV from a group of 61 individuals can amount to $7.7 \mathrm{fL}$ or $10.8 \mathrm{fL}$ [107].

Since MPV measurement is influenced by the type of anticoagulation [56], the preanalytical period [57] and the method of measurement [107] but has broadly been used as a prognostic biomarker in a growing number of studies [61, 62, 115-120], a standardized method must be found. Such standardization, in addition to the use of the same in vitro anticoagulant and the same measuring method, also encompasses the uniform pre-analytical treatment of the sample; that is, there should be the same time delay after the blood was taken. In their metaanalysis of such MPV studies, Lancé [17] and Beyan [63] demonstrated that such standardized conditions are generally not met, although Threatte (1984) and Towbridge (1985) had previously stated that there is a need for a standard reference method to obtain reliable results from MPV measurements [106, 121].

\section{Platelet activation parameters}

Besides their role in coagulation, platelets are involved in inflammatory processes [122-124], for example in recruiting leukocytes to inflammatory sites at the vascular defects $[125,126]$. Such recruitment is mainly realized by the formation of platelet-leukocyte aggregates (PLA) after previous platelet activation [127]. Platelet activation can be monitored by either measuring CD62p and CD63 expression or PLA formation. Increased levels of platelet activation markers and PLA are associated with liver cirrhosis [128], acute myocardial infarction [129], type 1 diabetes [130], rheumatoid arthritis [131] and systemic lupus erythematosus [132].

Several studies indicate that the time-dependent increase of platelet volume in EDTA anti-coagulated blood samples is accompanied by an increased expression of platelet activation markers P-selectin (CD62p) and granulophysin (CD63) [50, 133]. Initial experiments by Stenberg and colleagues showed that CD62p is present in unstimulated platelets in the $\alpha$-granule membrane and subsequently expressed in the surface-connected open canalicular system (SCS) after thrombin stimulation during degranulation [134]. In vivo, CD62p mediates the binding of activated platelets to leukocytes and the vascular endothelium via its $\mathrm{Ca}^{2+}$-dependent lectin domain [104, 135], thus supporting the recruitment of leukocytes to the endothelium defect $[136,137]$ and the formation of stable platelet aggregates [138].

Granulophysin (CD63) is a protein in the tetraspanin group and is found in, among others, the dense granules and the $\alpha$-granules of platelets $[139,140]$, as well as the azurophilic granules of neutrophils [141] and the WeibelPalade bodies of endothelial cells [142]. The interaction of CD63 with neutrophils leads to their activation and expression of CD11b/18 [103]. In vivo, binding of CD11b/18 with endothelial ICAM-1 leads to adhesion of neutrophils to the endothelial defect [143]. The fact that spontaneous platelet activation occurs in EDTA anti-coagulated blood has been known for almost 25 years [32]. In addition to its $\mathrm{Ca}^{2+}$-binding properties, EDTA affects membrane fluidity and the glycoprotein structure, in particular that of Gp IIb/IIIa [144, 145]. The morphological changes of platelets as induced by EDTA are similar to those caused by the binding of fibrinogen to the Gp IIb/IIIa receptor, which was demonstrated by experiments with platelets of thrombasthenia patients in citrated plasma [144, 146]. Since the application of heparin 
and EDTA anti-coagulated blood leads to spontaneous CD62p-expression, these anticoagulants are not suitable for measuring platelet activation [144]. For flow cytometric examinations of platelet activation, citrate anti-coagulated sample material and the combination of EDTA and citrate theophylline adenosine dipyridamole (EDTA-CTAD) are mainly used, as this combination causes significantly lower spontaneous platelet activation [50, 76, 111].

Macey and colleagues investigated, whether the parameter "mean platelet component" (MPC) as reported from the Advia analyzers could be a useful marker of platelet activation. MPC is mathematically derived by subtracting the RI of water (1.333) from the RI of platelets and dividing the difference by the average RI increment $(0.0018 \mathrm{dL} / \mathrm{g})$ [76]. The assumption of MPC as marker of platelet activation is, that a degranulation and subsequent surface expression of P-selectin leads to a decrease of platelet density, thus resulting in a lower MPC. Several studies showed that P-selectin expression and MPC are inversely correlated and a reduction of MPC indicates anticoagulant and thrombin induced platelet activation $[50,76,111,133]$. Therefore, MPC as an automated approach that can be determined from routineously measured blood samples is a time-saving alternative to the flow cytometric P-selectin measurement.

Until the 2000s, the measurement of P-selectin was considered a gold standard for detecting platelet activation, but since platelets lose P-selectin after degranulation and P-selectin-expressing platelets rapidly adhere to leukocytes via PSGL-1, the measurement of PLA is a more reliable marker of platelet activation [105, 147]. In order to apply PLA as a prognostic marker, standardized and reproducible procedures are required. Several authors have proposed protocols for PLA measurement [105, 148150], but they differ in terms of choice of anticoagulation, activation markers, sample preparation and data evaluation. For example, Harding and colleagues recommend measuring platelet-monocyte aggregates as the proportion of CD14- and CD42a-bearing cells using a direct thrombin inhibitor as the anticoagulant [149]. Nagasawa and colleagues applied citrate anti-coagulated blood samples and measured the proportion of CD41-positive monocytes, neutrophils and lymphocytes after their separation based on CD45 expression and side scatter properties [148]. Pearson et al. applied CTAD tubes and defined plateletmonocyte aggregates as cells positive for CD14 and CD61 [105]. For further insights regarding methodology and clinical implications of measuring PLA, the recent review by Finsterbusch and colleagues is recommended [151]. Bournazos and colleagues state that citrate anticoagulation only results in partial $\mathrm{Ca}^{2+}$ complexation, and, in contrast to EDTA, other divalent cations (e.g. $\mathrm{Mg}^{2+}$ ) are not complexed. The authors observed significantly lower percentages of platelets binding to monocytes in citrate anti-coagulated samples compared with hirudin, heparin or PPACK anti-coagulated samples, and, irrespective of the anticoagulant used, the incubation of the blood sample with EDTA resulted in a decrease of PLA [152].

The interaction between platelet P-selectin and leukocyte PSGL-1 is strictly $\mathrm{Ca}^{2+}$-dependent [153] and can only initiate after platelet activation and consequent granular expression of P-selectin [127, 128, 137, 154]. Several authors state in common $[149,150]$ that EDTA anticoagulated samples are not suitable for measuring PLA due to $\mathrm{Ca}^{2+}$ chelation. Experiments with hirudin anticoagulated blood showed that the subsequent addition of EDTA even leads to the dissociation of the plateletleukocyte complexes [155]. This is supported by the observation that EDTA causes high levels of CD62p but low levels of PLA. However, some authors have different views and state that the $\mathrm{Ca}^{2+}$-chelating properties of EDTA prevent artificial formation of PLA [151].

$\mathrm{MgSO}_{4}$ anticoagulation does not lead to cation complexation, and the $\mathrm{Ca}^{2+}$ effect on P-selectin-mediated platelet binding to leukocytes [135] is supported. In addition, Mannuß and colleagues showed that $\mathrm{MgSO}_{4}$ anticoagulation avoids in vitro platelet activation as effectively as citrate anticoagulation [8]. Given these findings, $\mathrm{MgSO}_{4}$ anticoagulation could be an alternative to the conventional use of citrate for flow cytometric studies on platelet activation and platelet-leukocyte interaction.

\section{Platelet function parameters}

\section{Light transmission aggregometry (LTA) according to Born}

In 1962, Gustav Victor Rudolf Born developed a turbidimetric method to measure platelet aggregation. This approach to measurement is based on the increase in light transmission through citrated platelet-rich plasma (PRP), which occurs due to the formation of platelet aggregates after platelet stimulation with ADP, ristocetin, arachidonic acid, epinephrine or collagen [156, 157]. For further technical insights concerning LTA and additional platelet function tests, the review by Paniccia and colleagues is recommended [158]. Over the years, several protocols for the preparation of PRP have been proposed $[159,160]$, but the guidelines of the ISTH recommend the centrifugation of citrated blood with $200 \mathrm{~g}$ for $10 \mathrm{~min}$ [161]. 


\section{Impedance aggregometry}

The measuring principle of an impedance aggregometer is based on the fact that platelets in hirudinized blood are activated and aggregate on the surface of sensor electrodes after stimulation by physiological agonists such as ADP, arachidonic acid, ristocetin, thrombin receptoractivating peptide-6 (TRAP-6) or collagen. After in vitro activation by one of these agonists, platelets express the glycoprotein receptor GpIIb/IIIa, which enables the platelet to attach to the sensor electrodes in the measuring cell. The aggregation of platelets on the surface of the two sensor electrodes causes an increase of electrical resistance (impedance) between them. This increase of resistance is measured continuously over $6 \mathrm{~min}$ and reported as the dimensionless unit AUC (area under the curve) [53,162].

The recommendations for the standardization of LTA from the SSC/ISTH state that LTA studies should be performed using sodium citrate anti-coagulated samples, buffered, at concentrations of $109 \mathrm{mM}$ or $129 \mathrm{mM}$ and the studies should be completed within $4 \mathrm{~h}$ after blood sampling [161]. Nevertheless, the application of citrated blood for platelet function tests is controversial since the $\mathrm{Ca}^{2+}$-binding properties of citrate create a non-physiological milieu in which the platelets are suspended [163, 164]. Direct comparisons of citrate and heparin anti-coagulated samples using LTA as well as impedance aggregometry revealed that, as measured with both methods, the platelet function was impaired in citrate anti-coagulated samples after $24 \mathrm{~h}$, whereas platelet function in heparin anti-coagulated blood was predominantly preserved [165]. However, other authors state that heparin is unsatisfactory due to in vitro platelet clumping and platelet adherence to the sampling device, resulting in low platelet numbers in PRP [166]. Since the $\mathrm{Ca}^{2+}$-binding is regarded as disadvantageous, alternative PRP preparations for LTA have been investigated. As demonstrated by Mani and colleagues, the arachidonic acidinduced platelet aggregation was stable up to $24 \mathrm{~h}$ after sampling in hirudin and BAPA (benzylsulfonyl-D-Arg-Pro4-amidinobenzylamide), whereas a significantly reduced platelet response was already observed after $12 \mathrm{~h}$ in citrate anti-coagulated blood [164]. BAPA, a dual inhibitor of factor $\mathrm{Xa}$ (FXa) and thrombin, is known to also be superior to hirudin in inhibiting thrombin generation and therefore providing a better sample stability over $48 \mathrm{~h}$ [167]. The problem of incomplete inhibition of thrombin formation by hirudin was confirmed by Chapman and Favaloro's observation that in some cases there is a time-dependent reduction in platelet aggregation, as measured with impedance aggregometry, and the formation of platelet clumps in hirudin anti-coagulated whole blood occurs even within the recommended $3 \mathrm{~h}$ test window [68].

Kalb and colleagues compared platelet function from blood samples that were anti-coagulated with direct thrombin inhibitors (melagatran, lepirudin and argatroban), citrate or heparin using impedance aggregometry. There were no significant differences in aggregability between the direct thrombin inhibitor samples and heparin samples, whereas the aggregation in citrated samples after stimulation from most of the agonists was impaired [168]. This finding is in accordance with several studies and supports the recommendation to apply hirudin in preference to citrate anti-coagulated samples $[53,165,169]$.

Kaiser and colleagues investigated the influence of in vitro anticoagulation, storage time and storage temperature on platelet function as measured by impedance aggregometry. They compared six in vitro anticoagulants and found that besides the hirudin anticoagulation, sodium heparin guarantees the longest storage time (up to $12 \mathrm{~h}$ for ADP tests and up to $24 \mathrm{~h}$ for arachidonic acid tests). Cold $\left(4^{\circ} \mathrm{C}\right)$ and warm $\left(37^{\circ} \mathrm{C}\right)$ storage temperatures had a negative effect on sample stability regardless of the applied in vitro anticoagulant. Therefore, the storage in sodium heparin or hirudin (concentration: $45 \mu \mathrm{g} / \mathrm{mL}$ ) anticoagulated samples at room temperature for no longer than $24 \mathrm{~h}$ is recommended [170].

When Mannuß and colleagues investigated platelet activation in $\mathrm{MgSO}_{4}$ anti-coagulated blood, they demonstrated that the stimulation with ADP and arachidonic acid leads to a similarly high state of platelet activation (proportion of CD62p- and CD63-positive platelets) as in citrate anti-coagulated blood, but the aggregation as induced by several agonists (ADP, arachidonic acid, ristocetin, collagen and TRAP) was lower in $\mathrm{MgSO}_{4}$ anti-coagulated blood than in the respective citrate or hirudin anticoagulated samples [171]. This observation suggests that $\mathrm{MgSO}_{4}$ anticoagulation has more far-reaching effects on platelets than citrate anticoagulation, which works primarily via $\mathrm{Ca}^{2+}$ withdrawal. Hwang and Ravn's observation that $\mathrm{Mg}^{2+}$ inhibits platelet aggregation in a dose-dependent manner [40,172] was confirmed by Mannuß et al., who focused on the effects of increasing $\mathrm{MgSO}_{4}$ concentrations in hirudin anti-coagulated blood sampling devices on impedance aggregometry [171]. The activated fibrinogen receptor Gp IIb/IIIa plays an important role in the formation of a stable platelet aggregate by recruiting further platelets via fibrinogen binding and ensuring the formation of a stable aggregate. Gawaz and colleagues showed that $\mathrm{Mg}^{2+}$ inhibits fibrinogen-mediated platelet aggregation 
regardless of the applied agonist and reduces platelet adhesion to immobilized fibrinogen [173].

\section{Summary and outlook}

Throughout the history of platelet measurement, several in vitro anticoagulants have been proposed and different measurement technologies established. This review notes the pre-analytical variability that arises due to the choice of in vitro anticoagulation and measurement technology for the determination of platelet parameters.

It is broadly recognized that in vitro anticoagulation affects blood cells (e.g., platelets) in terms of structural properties [18], state of activation [174] and intracellular signaling [40]. For example, EDTA, the standard anticoagulant for platelet counting, causes a time-dependent platelet shape change with consecutive spontaneous platelet activation, and, in rare cases, the EDTA-dependent PTCP can lead to misdiagnosis. Since this phenomenon has also been described for citrate and heparin [29, 30, 32], a reliable alternative for the correct estimation of platelet counts in suspected PTCP is $\mathrm{MgSO}_{4}$ [34].

As mentioned previously, automated hematology analyzers apply different measuring principles and algorithms to define a detected signal as a platelet or to sort it to another cell population. Several studies report that, when measuring from EDTA anti-coagulated blood, the impedance methods measure higher MPV values than the scatterlight method. However, the difference between the MPV values measured with different impedance methods may be even larger [75]. Therefore, studies on MPV and platelet counts that were performed with different analyzer technologies are poorly comparable, even if the same in vitro anticoagulant was applied. When performing measurements at different times after sampling from differently anti-coagulated blood samples, the results may vary even more. In order to improve the comparability of studies on MPV and platelet count measurement, a standardized study design must state the applied in vitro anticoagulant, the time delay after sampling and whether the measurements were performed on impedance, fluorescence optical or scatter light optical-based analyzers. Although the need for standardization of MPV measurements was identified in the early 1980s [106, 121], recent meta-analyses have revealed that the majority of studies on MPV as a biomarker lack standardized study designs $[17,63]$. This led to a new editorial policy defining minimum requirements for manuscripts addressing MPV as a prognostic marker in certain conditions [64].
For measurements of platelet activation by accessing the expression of activation markers (e.g. CD62p and CD63), it is necessary to take blood samples in anticoagulants that do not cause an increased spontaneous expression of platelet activation markers but mainly leave the platelets unaffected. Therefore, the application of heparin and EDTA anti-coagulated blood is not suitable for the measurement of platelet activation [144], and the application of citrate, $\mathrm{MgSO}_{4}$ or EDTA-CTAD anti-coagulated blood is recommended $[8,76,111]$. When choosing the approach by which to measure PLA formation, it is important to keep in mind that the formation is mainly mediated via PSGL-CD62p binding and is thus strictly $\mathrm{Ca}^{2+}$-dependent. Nevertheless, the proposed protocols for the measurement of PLA formation vary in the choice of in vitro anticoagulant, activation markers, sample preparation and data evaluation [105, 148-150].

As for MPV studies, there is a need for a standardized study design that states the applied in vitro anticoagulant, flow cytometry protocol and time delay after sampling in order to facilitate the comparison of acquired data.

Although there are reports that platelet response is better maintained over $24 \mathrm{~h}$ in heparin anti-coagulated blood [165] and PRP from hirudin anti-coagulated blood is more sensitive to show the effects of aspirin $[175,176]$, the recommendation of the SSC/ISTH is to perform the measurement of platelet function by LTA from citrate anti-coagulated blood [161]. Citrate anti-coagulated blood is also applied for the measurement of platelet function using impedance aggregometry [177, 178], but, according to several studies [53, 169, 170] and the manufacturer's recommendation, hirudin anticoagulated blood is preferable.

For all studies on platelet parameters, it is a prerequisite to adhere to recommended standardizations, prepare the study design accordingly and clearly state the study design.

Research funding: None declared.

Author contributions: The author has accepted responsibility for the entire content of this manuscript and approved its submission.

Competing interests: The author states no conflict of interest.

\section{References}

1. Nasse H. Mikroskopische Beobachtungen über die Bestandtheile des Bluts und der sich zur Faserhaut gestaltenden Flüssigkeit, besonders über deren Verhalten während der Gerinnung. In: Nasse $\mathrm{CF}$, Nasse $\mathrm{H}$, editors. Untersuchungen zur Physiologie und Pathologie. Bonn: Habicht; 1836. pp. 71-93. 
2. Schultze M. Ein heizbarer Objecttisch und seine Verwendung bei Untersuchungen des Blutes. Archiv f Mikrosk Anatomie 1865;1:142.

3. Schulten. Ergebnisse einiger Blutuntersuchungen in Puerperalkrankheiten. Archiv $\mathrm{f}$ pathol Anat 1858;14:501-9.

4. Bizzozero J. Ueber einen neuen Formbestandtheil des Blutes und dessen Rolle bei der Thrombose und der BlutgerinnungUntersuchungen. Arch Pathol Anat Physiol Klin Med 1882;90: 261-332.

5. Duke WW. The relation of blood platelets to hemorrhagic disease - Description of a method for determining the bleeding time and coagulation time and report of three cases of hemorrhagic disease relieved by transfusion. JAMA 1910;55:1185-92.

6. Kuter DJ. The physiology of platelet production. Stem Cells 1996; 14:88-101.

7. Wright JH. The histogenesis of the blood platelets. J Morphol 1910;21:263-78.

8. Mannuß S, Schuff-Werner P, Dreissiger K, Kohlschein P. Magnesium sulfate as an alternative in vitro anticoagulant for the measurement of platelet parameters?. Am J Clin Pathol 2016;145: 806-14.

9. Hoffmann JJML. Reference range of mean platelet volume. Thromb Res 2012;129:534-5.

10. Bath PMW, Butterworth RJ. Platelet size measurement, physiology and vascular disease. Blood Coagul Fibrinolysis 1996; 7:157-61.

11. Dyckerhoff H, Marx R, Ludwig B. Über den Wirkungsmechanismus und die Verwendbarkeit einiger blutgerinnungshemmender organischer Substanzen. Z Gesamte Exp Med 1942;110:412-42.

12. Proescher F. Anti-coagulant properties of ethylene bisiminodiacetic acid. Proc Soc Exp Biol Med 1951;76:619-20.

13. England JM, Rowan RM, Van Assendelft OW, Bull BS, Coulter WH, Fujimoto K, et al. Recommendations of the international council for standardization in haematology for ethylenediaminetetraacetic acid anticoagulation of blood for blood cell counting and sizing. Am J Clin Pathol 1993;100:371-2.

14. Lippi G, Plebani M. EDTA-dependent pseudothrombocytopenia: further insights and recommendations for prevention of a clinically threatening artifact. Clin Chem Lab Med 2012;50: 1281-5.

15. Banfi G, Salvagno GL, Lippi G. The role of ethylenediamine tetraacetic acid (EDTA) as in vitro anticoagulant for diagnostic purposes. Clin Chem Lab Med 2007;45:565-76.

16. Bonetti G, Cancelli V, Coccoli G, Piccinelli G, Brugnoni D, Caimi L, et al. Which sample tube should be used for routine glucose determination?. Prim Care Diabetes 2016;10:227-32.

17. Lancé MD, Sloep M, Henskens YMC, Marcus MAE. Mean platelet volume as a diagnostic marker for cardiovascular disease: drawbacks of preanalytical conditions and measuring techniques. Clin Appl Thromb Hemost 2012;18:561-8.

18. White JG. Effects of ethylenediamine tetracetic acid (EDTA) on platelet structure. Scand J Haematol 1968;5:241-54.

19. Thompson CB, Diaz DD, Quinn PG, Lapins M, Kurtz SR, Valeri CR. The role of anticoagulation in the measurement of platelet volumes. Am J Clin Pathol 1983;80:327-32.

20. Gowland E, Kay HE, Spillman JC, Williamson JR. Agglutination of platelets by a serum factor in the presence of EDTA. J Clin Pathol 1969;22:460-4.
21. Bartels PCM, Schoorl M, Lombarts AJPF. Screening for EDTA-dependent deviations in platelet counts and abnormalities in platelet distribution histograms in pseudothrombocytopenia. Scand J Clin Lab Invest 1997;57:629-36.

22. Lau LG, Chng WJ, Liu TC. Unnecessary transfusions due to pseudothrombocytopenia. Transfusion 2004;44:801.

23. Kohlschein P, Bänsch D, Dreißiger K, Schuff-Werner P. Exclusion of thrombocytopenia as a contraindication for invasive radiofrequency ablation in a patient with paroxysmal atrial fibrillation by using magnesium anticoagulation instead of EDTA: another case of anticoagulant-induced pseudothrombocytopenia. Heart Surg Forum 2015;18:E90-2.

24. Kocum TH, Katircibasi TM, Sezgin AT, Atalay H. An unusual cause of mismanagement in an acute myocardial infarction case: pseudothrombocytopenia. Am J Emerg Med 2008;26:740e1-e2.

25. Yoshikawa T, Nakanishi K, Maruta T, Takenaka D, Hirota S, Matsumoto S, et al. Anticoagulant-induced pseudothrombocytopenia occurring after transcatheter arterial embolization for hepatocellular carcinoma. Jpn J Clin Oncol 2006; 36:527-31.

26. Yoshikawa H. EDTA-dependent pseudothrombocytopenia induced by valproic acid. Neurology 2003;61:579-80.

27. Wenzel F, Lasshofer R, Rox J, Fischer J, Giers G. Transient appearance of postoperative EDTA-dependent pseudothrombocytopenia in a patient after gastrectomy. Platelets 2011;22:74-6.

28. Mori M, Kudo H, Yoshitake S, Ito K, Shinguu C, Noguchi T. Transient EDTA-dependent pseudothrombocytopenia in a patient with sepsis. Intensive Care Med 2000;26:218-20.

29. Dima F, Salvagno GL, Dima F, Salvagno GL, Danese E, Veneri D, et al. An unusual case of sodium citrate-dependent artifactual platelet count. Intervent Med Appl Sci 2019;100:1-4.

30. Kovacs F, Varga M, Pataki Z, Rigo E. Pseudothrombocytopenia with multiple anticoagulant sample collection tubes. Intervent Med Appl Sci 2016;8:181-3.

31. Zhou X, Wu X, Deng W, Li J, Luo W. Amikacin can be added to blood to reduce the fall in platelet count. Am J Clin Pathol 2011;136: 646-52.

32. Schrezenmeier H, Müller H, Gunsilius E, Heimpel H, Seifried E. Anticoagulant-induced pseudothrombocytopenia and pseudoleucocytosis. Thromb Haemost 1995;73:506-13.

33. Rosenkranz B, Wisser H, Bode JC. Pseudothrombopenie-eine Störung der Thrombozytenzahlbestimmung. Dtsch Med Wochenschr 1985;110:492-5.

34. Schuff-Werner P, Steiner M, Fenger S, Groß HJ, Bierlich A, Dreissiger $\mathrm{K}$, et al. Effective estimation of correct platelet counts in pseudothrombocytopenia using an alternative anticoagulant based on magnesium salt. Br J Haematol 2013; 162:684-92.

35. Fonio A. Über ein neues Verfahren der Blutplättchenzählung. Deutsche Zeitschrift f. Chirurgie 1912;117:176-94.

36. Nakamoto K, Sugibayashi S, Takahashi A, Terauchi S, Hada A, Munakata M, et al. Platelet count in EDTA-dependent pseudothrombocytopenia-application of $\mathrm{MgSO} 4$ as an anticoagulant. Rinsho Byori. Jpn J Clin Pathol 1986;34:167-73.

37. Kondo H, Kobayashi E, Itani T, Tatsumi N, Tsuda I. Hematology tests of blood anticoagulated with magnesium sulphate. Southeast Asian J Trop Med Public Health 2002;33:6-9. 
38. Jankun J, Skrzypczak-Jankun E, Lipinski B. Complex function of magnesium in blood clot formation and lysis. Cent Eur J Immunol 2013;38:149-53.

39. Gawaz M. Antithrombotic effects of magnesium. Possible therapeutic consequences for acute coronary syndromes | Antithrombozytare Wirksamkeit von Magnesium. Mogliche Konsequenzen fur die akut ischamische Herzerkrankung. Fortschr Med 1996;114:47-50.

40. Hwang DL, Yen CF, Nadler JL. Effect of extracellular magnesium on platelet activation and intracellular calcium mobilization. Am J Hypertens 1992;5:700-6.

41. Adcock DM, Kressin DC, Marlar RA. Effect of $3.2 \%$ vs $3.8 \%$ sodium citrate concentration on routine coagulation testing. Am J Clin Pathol 1997;107:105-10.

42. Mann KG, Whelihan MF, Butenas S, Orfeo T. Citrate anticoagulation and the dynamics of thrombin generation. J Thromb Haemostasis 2007;5:2055-61.

43. Quick AJ, Stefanini M. The chemical state of the calcium reacting in the coagulation of blood. J Gen Physiol 1948;32: 191-202.

44. Perrotta G, Roberts L, Glazier J, Schumacher HR. Use of sodium citrate anticoagulant for routine hematology analysis on the CELL-DYN ${ }^{8}$ 4000: an opportunity to enhance efficiency in the clinical laboratory. Lab Hematol 1998;4:156-62.

45. Shum HP, Yan WW, Chan TM. Risks and benefits of citrate anticoagulation for continuous renal replacement therapy. Hong Kong Med J 2015;21:149-54.

46. McLean J. The thromboplastic action of cephalin. Am J PhysiolLegacy Content 1916;41:250-7.

47. Howell WH, Holt E. Two new factors in blood coagulationheparin and pro-antithrombin. Am J Physiol-Legacy Content 1918; 47:328-41.

48. Jin L, Abrahams JP, Skinner R, Petitou M, Pike RN, Carrell RW. The anticoagulant activation of antithrombin by heparin. Proc Natl Acad Sci USA 1997;94:14683-8.

49. Narayanan S. The preanalytic phase. An important component of laboratory medicine. Am J Clin Pathol 2000;113:429-52.

50. Macey M, Azam U, McCarthy D, Webb L, Chapman ES, Okrongly D, et al. Evaluation of the anticoagulants EDTA and citrate, theophylline, adenosine, and dipyridamole (CTAD) for assessing platelet activation on the ADVIA 120 hematology system. Clin Chem 2002;48:891-9.

51. Haycraft JB. Ueber die Einwirkung eines Secretes des officinellen Blutegels auf die Gerinnbarkeit des Blutes. Archiv $\mathrm{f}$ experiment Pathol u Pharmakol 1884;18:209-17.

52. Stone SR, Hofsteenge J. Kinetics of the inhibition of thrombin by hirudin. Biochemistry 1986;25:4622-8.

53. Toth O, Calatzis A, Penz S, Losonczy H, Siess W. Multiple electrode aggregometry: A new device to measure platelet aggregation in whole blood. Thromb Haemost 2006;96:781-8.

54. Bath PM. The routine measurement of platelet size using sodium citrate alone as the anticoagulant. Thromb Haemost 1993;70: 687-90.

55. McShine RL, Das PC, Smit Sibinga CT, Brozovic B. Differences between the effects of EDTA and citrate anticoagulants on platelet count and mean platelet volume. Clin Lab Haematol 1990;12:277-85.

56. Dastjerdi MS, Emami T, Najafian A, Amini M. Mean platelet volume measurement, EDTA or citrate?. Hematology 2006;11:317-9.
57. Lancé MD, van Oerle R, Henskens YMC, Marcus MAE. Do we need time adjusted mean platelet volume measurements?. Lab Hematol 2010;16:28-31.

58. O'Malley T, Ludlam CA, Fox KA, Elton RA. Measurement of platelet volume using a variety of different anticoagulant and antiplatelet mixtures. Blood Coagul Fibrinolysis 1996;7:431-6.

59. Korniluk A, Koper-Lenkiewicz OM, Kamińska J, Kemona H, Dymicka-Piekarska V. Mean platelet volume (MPV): new perspectives for an old marker in the course and prognosis of inflammatory conditions. Mediators Inflamm 2019. Article ID: 9213074. https://doi.org/10.1155/2019/9213074.

60. Navya BN, Dhanalakshmi DP, Vivek TG, Kariappa TM. Evaluation of mean platelet volume as a prognostic marker in type II diabetes mellitus. J Evol Med Dent Sci 2015;04:3261-6.

61. Lippi G, Filippozzi L, Salvagno GL, Montagnana M, Franchini M, Guidi GC, et al. Increased mean platelet volume in patients with acute coronary syndromes. Arch Pathol Lab Med 2009;133: 1441-3.

62. Chu SG, Becker RC, Berger PB, Bhatt DL, Eikelboom JW, Konkle B, et al. Mean platelet volume as a predictor of cardiovascular risk: a systematic review and meta-analysis. J Thromb Haemostasis 2010;8:148-56.

63. Beyan C, Beyan E. Were the measurements standardized sufficiently in published studies about mean platelet volume? Blood Coagul Fibrinolysis 2016;27:0-0.

64. Harrison P, Goodall AH. Studies on mean platelet volume (MPV)new editorial policy. Platelets 2016;27:605-6.

65. Kumura T, Hino M, Yamane T, Tatsumi N. Hirudin as an anticoagulant for both haematology and chemistry tests. J Autom Methods Manag Chem 2000;22:109-12.

66. Johnston LR, Larsen PD, La Flamme AC, Harding SA. Methodological considerations for the assessment of ADP induced platelet aggregation using the Multiplate ${ }^{\circledR}$ analyser. Platelets 2013;24:303-7.

67. Menssen HD, Melber K, Brandt N, Thiel E. The use of hirudin as universal anticoagulant in haematology, clinical chemistry and blood grouping. Clin Chem Lab Med 2001;39:1267-77.

68. Chapman K, Favaloro EJ. Time dependent reduction in platelet aggregation using the multiplate analyser and hirudin blood due to platelet clumping. Platelets 2018;29:305-8.

69. Hayem G. Recherches sur l'évolution des hématies dans le sang de l'homme et des vertébrés. In: Archives de physiologie normale et pathologique. Paris: G. Masson; 1878.

70. Graham MD. The Coulter principle: foundation of an industry. JALA-J Assoc Lab Autom 2003;8:72-81.

71. Briggs C, Harrison P, Machin SJ. Continuing developments with the automated platelet count. Int J Lab Hematol 2007;29:77-91.

72. Brecher G, Schneiderman M, Cronkite E. The reproducibility and constancy of the platelet count. Am J Clin Pathol 1953;23:15-26.

73. World Health Organization, Health Laboratory Technology Unit. Recommended methods for the visual determination of white cell and platelet counts 1988.

74. Briggs C, Longair I, Kumar P, Singh D, Machin SJ. Performance evaluation of the Sysmex haematology XN modular system. J Clin Pathol 2012;65:1024-30.

75. Latger-Cannard V, Hoarau M, Salignac S, Baumgart D, Nurden P, Lecompte T. Mean platelet volume: comparison of three analysers towards standardization of platelet morphological phenotype. Int J Lab Hematol 2012;34:300-10. 
76. Macey MG, Carty E, Webb L, Chapman ES, Zelmanovic D, Okrongly $D$, et al. Use of mean platelet component to measure platelet activation on the ADVIA 120 haematology system. Cytometry 1999;38:250-5.

77. Wilson JD, Foster TH. Mie theory interpretations of light scattering from intact cells. Opt Lett 2005;30:2442-4.

78. Stanworth SJ, Denton K, Monteath J, Patton WN. Automated counting of platelets on the Bayer ADVIA(TM) 120 analyser. Clin Lab Haematol 1999;21:113-7.

79. Kunicka JE, Fischer G, Murphy J, Zelmanovic D. Improved platelet counting using two-dimensional laser light scatter. Am J Clin Pathol 2000;114:283-9.

80. Mohamed-Rachid B, Raya AF, Sulaiman AH, Salam AK. Comparative analysis of four methods for enumeration of platelet counts in thrombocytopenic patients. J Appl Hematol 2015;6:11924.

81. van der Beken Y, van Dalem A, van Moer G, Segers E, Damiaens S, Hoffmann J, et al. Performance evaluation of the prototype Abbott Alinity hq hematology analyzer. Int J Lab Hematol 2019;41:44855.

82. Mach WJ, Thimmesch AR, Orr JA, Slusser JG, Pierce JD. Flow cytometry and laser scanning cytometry, a comparison of techniques. J Clin Monit Comput 2010;24:251-9.

83. Michelson AD. Flow cytometry: a clinical test of platelet function. Blood 1996;87:4925-36.

84. Briggs C, Kunka S, Machin SJ. The most accurate platelet count on the Sysmex XE-2100. Optical or impedance?. Clin Lab Haematol 2004;26:157-8.

85. Hoffmann JJML, van den Broek NMA, Curvers J. Reference intervals of reticulated platelets and other platelet parameters and their associations. Arch Pathol Lab Med 2013;137:1635-40.

86. Abe Y, Wada H, Tomatsu H, Sakaguchi A, Nishioka J, Yabu Y, et al. A simple technique to determine thrombopoiesis level using immature platelet fraction (IPF). Thromb Res 2006;118:463-9.

87. Buttarello M, Mezzapelle G, Freguglia F, Plebani M. Reticulated platelets and immature platelet fraction: clinical applications and method limitations. Int J Lab Hematol 2020;00:1-8.

88. Hoffmann JJML. Reticulated platelets: analytical aspects and clinical utility. Clin Chem Lab Med 2014;52:1107-17.

89. Briggs C, Kunka S, Hart D, Shinichiro O, Machin SJ. Assessment of an immature platelet fraction (IPF) in peripheral thrombocytopenia. Br J Haematol 2004;126:93-9.

90. Meintker L, Haimerl M, Ringwald J, Krause SW. Measurement of immature platelets with Abbott CD-Sapphire and Sysmex XE5000 in haematology and oncology patients. Clin Chem Lab Med 2013;51:2125-31.

91. Saigo K, Sakota Y, Masuda Y, Matsunaga K, Takenokuchi M, Nishimura K, et al. Automatic detection of immature platelets for decision making regarding platelet transfusion indications for pediatric patients. Transfus Apher Sci 2008;38:127-32.

92. Takami A, Shibayama M, Orito M, Omote M, Okumura H, Yamashita T, et al. Immature platelet fraction for prediction of platelet engraftment after allogeneic stem cell transplantation. Bone Marrow Transplant 2007;39:501-7.

93. Dadu T, Sehgal K, Joshi M, Khodaiji S. Evaluation of the immature platelet fraction as an indicator of platelet recovery in dengue patients. Int J Lab Hematol 2014;36:499-504.

94. Saigo K, Takenokuchi M, Imai J, Numata K, Isono S, Zenibayashi $M$, et al. Usefulness of immature platelet fraction for the clinical evaluation of myelodysplastic syndromes. Lab Hematol 2009;15: 13-6.

95. Hubert RM, Rodrigues MV, Andreguetto BD, Santos TM, Gilberti MP, Castro V, et al. Association of the immature platelet fraction with sepsis diagnosis and severity. Sci Rep 2015;5:8019.

96. Nishiyama M, Hayashi S, Kabutomori O, Yamanishi H, Suehisa E, Kurata $Y$, et al. Effects of anticoagulants and storage temperature on immature platelet fraction \% (IPF\%) values in stored samples measured by the automated hematology analyzer, XE-5000-utility of CTAD-anticoagulation and room temperature storage. Rinsho Byori 2011;59:452-8.

97. Tanaka Y, Tanaka Y, Gondo K, Maruki Y, Kondo T, Asai S, et al. Performance evaluation of platelet counting by novel fluorescent dye staining in the $\mathrm{XN}$-series automated hematology analyzers. J Clin Lab Anal 2014;28:341-8.

98. Seo JY, Lee S-T, Kim S-H. Performance evaluation of the new hematology analyzer Sysmex XN-series. Int J Lab Hematol 2015; 37:155-64.

99. Park SH, Park C-J, Kim M-J, Han M-Y, Lee B-R, Cho Y-U, et al. The Sysmex XN-2000 hematology autoanalyzer provides a highly accurate platelet count than the former Sysmex XE-2100 system based on comparison with the CD41/CD61 immunoplatelet reference method of flow cytometry. Ann Lab Med 2014;34:47174.

100. Schoorl M, Schoorl M, Oomes J, Van Pelt J. New fluorescent method (PLT-F) on sysmex XN2000 hematology analyzer achieved higher accuracy in low platelet counting. Am J Clin Pathol 2013;140:495-9.

101. ICSH. Platelet counting by the RBC/platelet ratio method: a reference method. Am J Clin Pathol 2001;115:460-4.

102. Trabuio E, Valverde S, Antico F, Manoni F, Gessoni G. Performance of automated platelet quantification using different analysers in comparison with an immunological reference method in thrombocytopenic patients. Blood Transfus 2009;7:43-8.

103. Skubitz KM, Campbell KD, Skubitz AP. CD63 associates with CD11/CD18 in large detergent-resistant complexes after translocation to the cell surface in human neutrophils. FEBS Lett 2000;469:52-6.

104. Bajorath J, Hollenbaugh D, King G, Harte W, Eustice DC, Darveau RP, et al. CD62/P-selectin binding sites for myeloid cells and sulfatides are overlapping. Biochemistry 1994;33: 1332-9.

105. Pearson L, Thom J, Adams M, Oostryck R, Krueger R, Yong G, et al. A rapid flow cytometric technique for the detection of platelet-monocyte complexes, activated platelets and plateletderived microparticles. Int J Lab Hematol 2009;31:430-9.

106. Towbridge EA. The routine measurement of platelet volume: a comparison of light-scattering and aperture-impedance technologies. Clin Phys Physiol Meas 1985;6:221-38.

107. Mannuß S, Kohlschein P, Dreißiger K, Schuff-Werner P. Measurement of platelet counts and volume using magnesium sulfate as an anticoagulant: comparison of impedance and lightscatter technology. Am J Clin Pathol 2016;146:538-45.

108. François D, Masure A, Atallah N, Touil L, Vasse M. Underestimation of platelet count on magnesium saltanticoagulated samples. Clin Chem Lab Med 2014;52:e95-7.

109. Shimizu M, Yamamoto M, Miyachi H, Shinohara Y, Ando Y. Simple, rapid, and automated method for detection of 
hyperaggregability of platelets using a hematology analyzer. Am J Hematol 2003;72:282-3.

110. Harrison P, Briggs C. Platelet counting. In: Michelson AD, editor. Platelets. Waltham: Academic Press; 2013. pp. 547-57.

111. Ahnadi CE, Sabrinah Chapman E, Lépine M, Okrongly D, PujolMoix N, Hernandez A, et al. Assessment of platelet activation in several different anticoagulants by the Advia 120 hematology system, fluorescence flow cytometry, and electron microscopy. Thromb Haemost 2003;90:940-8.

112. Hedberg P, Lehto T. Aging stability of complete blood count and white blood cell differential parameters analyzed by Abbott CELL-DYN Sapphire hematology analyzer. Int J Lab Hematol 2009;31:87-96.

113. Slim CL, Wevers BA, Demmers MWHJ, Lakos G, Hoffmann JJML, Adriaansen $\mathrm{HJ}$, et al. Multicenter performance evaluation of the Abbott Alinity hq hematology analyzer. Clin Chem Lab Med 2019; 57:1988-98.

114. Woo K-S, Jeong I-H, An G-D, Lim H-H, Han J-Y. Performance evaluation of new Abbott Alinity hq hematology analyzer. Int J Lab Hematol 2019;41:657-63.

115. Sun W, Zhang J, Cao Z, Li Y, Wang R. A decreased mean platelet volume is associated with stable and exacerbated asthma. Respiration 2014;88:31-7.

116. Qi X, Wan F, Lou Y, Ye B, Wu D. The mean platelet volume is a potential biomarker for cirrhosis in chronic hepatitis B virus infected patients. Hepatogastroenterology 2014;61:456-9.

117. Ju HY, Kim JK, Hur SM, Woo SA, Park KA, Park MY, et al. Could mean platelet volume be a promising biomarker of progression of chronic kidney disease?. Platelets 2015;26:143-7.

118. Han L, Han T, Nie C, Zhang Q, Cai J. Elevated mean platelet volume is associated with poor short-term outcomes in hepatitis $B$ virus-related acute-on-chronic liver failure patients. Clin Res Hepatol Gastroenterol 2015;39:331-9.

119. Goncalves SC, Labinaz M, Le May M, Glover C, Froeschl M, Marquis J-F, et al. Usefulness of mean platelet volume as a biomarker for long-term outcomes after percutaneous coronary intervention. Am J Cardiol 2011;107:204-9.

120. Erdem H, Aktimur R, Cetinkunar S, Reyhan E, Gokler C, Irkorucu 0 , et al. Evaluation of mean platelet volume as a diagnostic biomarker in acute appendicitis. Int J Clin Exp Med 2015;8: 1291-5.

121. Threatte GA, Adrados C, Ebbe S, Brecher G. Mean platelet volume: the need for a reference method. Am J Clin Pathol 1984; 81:769-72.

122. Siegel-Axel D, Langer H, Lindemann S, Gawaz M. Role of platelets in atherosclerosis and inflammation. Med Klin (Munich) 2006;101:467-75.

123. Gawaz M, Langer H, May AE. Platelets in inflammation and atherogenesis. J Clin Invest 2005;115:3378-84.

124. Klinger MHF, Jelkmann W. Review: role of blood platelets in infection and inflammation. J Interferon Cytokine Res 2002;22: 913-22.

125. Zuchtriegel G, Uhl B, Puhr-Westerheide D, Pörnbacher M, Lauber $\mathrm{K}$, Krombach F, et al. Platelets guide leukocytes to their sites of extravasation. PLoS Biol 2016;14:e1002459.

126. May $A E$, Seizer $P$, Gawaz M. Platelets: inflammatory firebugs of vascular walls. Arterioscler Thromb Vasc Biol 2008;28: s5-10.

127. Dole VS, Bergmeier W, Mitchell HA, Eichenberger SC, Wagner DD. Activated platelets induce Weibel-Palade-body secretion and leukocyte rolling in vivo: role of P-selectin. Blood 2005;106: 2334-9.

128. Panasiuk A, Zak J, Kasprzycka E, Janicka K, Prokopowicz D. Blood platelet and monocyte activations and relation to stages of liver cirrhosis. World J Gastroenterol 2005;11:2754-8.

129. Furman MI, Barnard MR, Krueger LA, Fox ML, Shilale EA, Lessard DM, et al. Circulating monocyte-platelet aggregates are an early marker of acute myocardial infarction. J Am Coll Cardiol 2001;38: 1002-6.

130. Harding SA, Sommerfield AJ, Sarma J, Twomey PJ, Newby DE, Frier BM, et al. Increased CD40 ligand and platelet-monocyte aggregates in patients with type 1 diabetes mellitus. Atherosclerosis 2004;176:321-5.

131. Bunescu A, Seideman P, Lenkei R, Levin K, Egberg N. Enhanced Fcgamma receptor I, alphaMbeta2 integrin receptor expression by monocytes and neutrophils in rheumatoid arthritis: interaction with platelets. J Rheumatol 2004;31: 2347-55.

132. Joseph JE, Harrison P, Mackie IJ, Isenberg DA, Machin SJ. Increased circulating platelet-leucocyte complexes and platelet activation in patients with antiphospholipid syndrome, systemic lupus erythematosus and rheumatoid arthritis. $\mathrm{Br}$ J Haematol 2001;115:451-9.

133. Diaz-Ricart M, Brunso L, Pino M, Navalon F, Jou JM, Heras M, et al. Preanalytical treatment of EDTA-anticoagulated blood to ensure stabilization of the mean platelet volume and component measured with the ADVIA counters. Thromb Res 2010;126:e30-5.

134. Stenberg PE, McEver RP, Shuman MA, Jacques YV, Bainton DF. A platelet alpha-granule membrane protein (GMP-140) is expressed on the plasma membrane after activation. J Cell Biol 1985;101:880-6.

135. Geng JG, Bevilacquat MP, Moore KL, McIntyre TM, Prescott SM, Kim JM, et al. Rapid neutrophil adhesion to activated endothelium mediated by GMP-140. Nature 1990;343:757-60

136. Smyth SS, McEver RP, Weyrich AS, Morrell CN, Hoffman MR, Arepally GM, et al. Platelet functions beyond hemostasis. I Thromb Haemostasis 2009;7:1759-66.

137. McEver RP, Cummings RD. Perspectives series: cell adhesion in vascular biology. Role of PSGL-1 binding to selectins in leukocyte recruitment. J Clin Invest 1997;100:485-91.

138. Merten M, Thiagarajan P. P-selectin expression on platelets determines size and stability of platelet aggregates. Circulation 2000;102:1931-6.

139. Pols MS, Klumperman J. Trafficking and function of the tetraspanin CD63. Exp Cell Res 2009;315:1584-92.

140. Nishibori M, Cham B, McNicol A, Shalev A, Jain N, Gerrard JM. The protein CD63 is in platelet dense granules, is deficient in a patient with Hermansky-Pudlak syndrome, and appears identical to granulophysin. J Clin Invest 1993;91:1775-82.

141. Cham BP, Gerrard JM, Bainton DF. Granulophysin is located in the membrane of azurophilic granules in human neutrophils and mobilizes to the plasma membrane following cell stimulation. Am J Pathol 1994;144:1369-80.

142. Vischer UM, Wagner DD. CD63 is a component of Weibel-Palade bodies of human endothelial cells. Blood 1993;82:1184-91.

143. Downey DG, Bell SC, Elborn JS. Neutrophils in cystic fibrosis. Thorax 2009;64:81-8.

144. Golanski J, Pietrucha T, Baj Z, Greger J, Watala C. Molecular insights into the anticoagulant-induced spontaneous activation 
of platelets in whole blood-various anticoagulants are not equal. Thromb Res 1996;83:199-216.

145. Watala C, Golański J, Boncler MA, Pietrucha T, Gwozdzinski K. Membrane lipid fluidity of blood platelets: a common denominator that underlies the opposing actions of various agents that affect platelet activation in whole blood. Platelets 1998;9:315-27.

146. Lages B, Weiss HJ. Evidence for a role of glycoprotein IIb-IIla, distinct from its ability to support aggregation, in platelet activation by ionophores in the presence of extracellular divalent cations. Blood 1994;83:2549-59.

147. Michelson AD, Barnard MR, Krueger LA, Valeri CR, Furman MI. Circulating monocyte-platelet aggregates are a more sensitive marker of in vivo platelet activation than platelet surface P-selectin: studies in baboons, human coronary intervention, and human acute myocardial infarction. Circulation 2001;104: 1533-7.

148. Nagasawa A, Matsuno K, Tamura S, Hayasaka K, Shimizu C, Moriyama T. The basis examination of leukocyte-platelet aggregates with CD45 gating as a novel platelet activation marker. Int J Lab Hematol 2013;35:534-41.

149. Harding SA, Din JN, Sarma J, Jessop A, Weatherall M, Fox KAA, et al. Flow cytometric analysis of circulating platelet-monocyte aggregates in whole blood: methodological considerations. Thromb Haemost 2007;98:451-6.

150. Hagberg IA, Lyberg T. Blood platelet activation evaluated by flow cytometry: optimised methods for clinical studies. Platelets 2000;11:137-50.

151. Finsterbusch M, Schrottmaier WC, Kral-Pointner JB, Salzmann M, Assinger A. Measuring and interpreting platelet-leukocyte aggregates. Platelets 2018;29:677-85.

152. Bournazos S, Rennie J, Hart SP, Dransfield I. Choice of anticoagulant critically affects measurement of circulating platelet-leukocyte complexes. Arterioscler Thromb Vasc Biol 2008;28:E2-3.

153. Sako D, Comess KM, Barone KM, Camphausen RT, Cumming DA, Shaw GD. A sulfated peptide segment at the amino terminus of PSGL-1 is critical for P-selectin binding. Cell 1995;83:323-31.

154. Hamburger SA, McEver RP. GMP-140 mediates adhesion of stimulated platelets to neutrophils. Blood 1990;75:550-4.

155. Zhao L, Bath PM, May J, Lösche W, Heptinstall S. P-selectin, tissue factor and CD40 ligand expression on platelet-leucocyte conjugates in the presence of a GPIIb/IIla antagonist. Platelets 2003;14:473-80.

156. Knöfler R, Eberl W, Schulze H, Bakchoul T, Bergmann F, Gehrisch $S$, et al. Diagnose angeborener Störungen der Thrombozytenfunktion. Interdisziplinäre S2K-Leitlinie der Ständigen Kommission Pädiatrie der Gesellschaft für Thrombose- und Hämostaseforschung e. V. Hämostaseologie 2014;34:201-12.

157. Born GV. Aggregation of blood platelets by adenosine diphosphate and its reversal. Nature 1962;194:927-9.

158. Paniccia R, Priora R, Liotta AA, Abbate R. Platelet function tests: a comparative review. Vasc Health Risk Manag 2015;11:133-48.

159. Femia EA, Pugliano M, Podda G, Cattaneo M. Comparison of different procedures to prepare platelet-rich plasma for studies of platelet aggregation by light transmission aggregometry. Platelets 2012;23:7-10.
160. Cattaneo M, Hayward CPM, Moffat KA, Pugliano MT, Liu Y, Michelson AD. Results of a worldwide survey on the assessment of platelet function by light transmission aggregometry: a report from the platelet physiology subcommittee of the SSC of the ISTH. J Thromb Haemostasis 2009;7:1029.

161. Cattaneo M, Cerletti C, Harrison P, Hayward CPM, Kenny D, Nugent $\mathrm{D}$, et al. Recommendations for the standardization of light transmission aggregometry: a consensus of the working party from the platelet physiology subcommittee of SSC/ISTH. J Thromb Haemostasis 2013;11:1183-9.

162. Mueller T, Dieplinger B, Poelz W, Calatzis A, Haltmayer M. Utility of whole blood impedance aggregometry for the assessment of clopidogrel action using the novel multiplate analyzercomparison with two flow cytometric methods. Thromb Res 2007;121:249-58.

163. Packham MA, Bryant NL, Guccione MA, Kinlough-Rathbone RL, Mustard JF. Effect of the concentration of $\mathrm{Ca} 2+$ in the suspending medium on the responses of human and rabbit platelets to aggregating agents. Thromb Haemost 1989;62: 968-76.

164. Mani $\mathrm{H}$, Hellis $M$, Lindhoff-Last $\mathrm{E}$. Platelet function testing in hirudin and BAPA anticoagulated blood. Clin Chem Lab Med 2011;49:501-7.

165. Truss NJ, Armstrong PCJ, Liverani E, Vojnovic I, Warner TD. Heparin but not citrate anticoagulation of blood preserves platelet function for prolonged periods. J Thromb Haemostasis 2009;7:1897-905.

166. Rand ML, Leung R, Packham MA. Platelet function assays. Transfus Apher Sci 2003;28:307-17.

167. Hellstern P, Stürzebecher U, Wuchold B, Haubelt H, Seyfert UT, Bauer M, et al. Preservation of in vitro function of platelets stored in the presence of a synthetic dual inhibitor of factor Xa and thrombin. J Thromb Haemostasis 2007;5: 2119-26.

168. Kalb ML, Potura L, Scharbert G, Kozek-Langenecker SA. The effect of ex vivo anticoagulants on whole blood platelet aggregation. Platelets 2009;20:7-11.

169. Wallén N, Ladjevardi M, Albert J, Bröijersen A. Influence of different anticoagulants on platelet aggregation in whole blood; a comparison between citrate, low molecular mass heparin and hirudin. Thromb Res 1997;87:151-7.

170. Kaiser AFC, Neubauer H, Franken CC, Krüger J-C, Mügge A, Meves $\mathrm{SH}$. Which is the best anticoagulant for whole blood aggregometry platelet function testing?. Comparison of six anticoagulants and diverse storage conditions. Platelets 2012; 23:359-67.

171. Mannuß S, Schuff-Werner P, Dreißiger K, Burstein C. Inhibition of agonist-induced platelet aggregation by magnesium sulfate warrants its use as an alternative in vitro anticoagulant in pseudothrombocytopenia. Platelets 2020; 31:680-4.

172. Ravn HB, Kristensen SD, Vissinger H, Husted SE. Magnesium inhibits human platelets. Blood Coagul Fibrinolysis 1996;7: 241-4.

173. Gawaz M, Ott I, Reininger AJ, Neumann FJ. Effects of magnesium on platelet aggregation and adhesion. Magnesium modulates surface expression of glycoproteins on platelets in vitro and ex vivo. Thromb Haemost 1994;72:912-8. 
174. Nishioka T, Yokota M, Tsuda I, Tatsumi N. Flow cytometric analysis of platelet activation under calcium ion-chelating conditions. Clin Lab Haematol 2002;24:115-9.

175. Basic-Micic M, Rauschenbach C, Demgen G, Krupinski K, Dechent C, Roman C, et al. Hirudin as anticoagulant to investigate platelet function. Hämostaseologie 1991;11:114-21.

176. Breddin HK. Can platelet aggregometry be standardized?. Platelets 2005;16:151-8.
177. Seyfert UT, Haubelt H, Vogt A, Hellstern P. Variables influencing multiplate(TM) whole blood impedance platelet aggregometry and turbidimetric platelet aggregation in healthy individuals. Platelets 2007;18:199-206.

178. Scharbert G, Kalb M, Marschalek C, Kozek-Langenecker SA. The effects of test temperature and storage temperature on platelet aggregation: a whole blood in vitro study. Anesth Analg 2006; 102:1280-4. 